\title{
Molecular Characterization and Identification of Stubby Root Nematode Species From Multiple States in the United States
}

\author{
Danqiong Huang, Guiping Yan, ${ }^{\dagger}$ and Neil Gudmestad, North Dakota State University, Department of Plant Pathology, Fargo 58102; \\ Jonathan Whitworth, United States Department of Agriculture-Agricultural Research Service (USDA-ARS), Aberdeen, ID 83210; Kenneth \\ Frost, Oregon State University, Hermiston Agricultural Research and Extension Center, Hermiston 97838; Charles Brown, USDA-ARS, \\ Prosser, WA 99350; Weimin Ye, North Carolina Department of Agriculture and Consumer Services, Raleigh 27607; Paula Agudelo, Clemson \\ University, Plant and Environmental Sciences Department, Clemson, SC 29634; and William Crow, University of Florida, Entomology and \\ Nematology Department, Gainesville 32611
}

\begin{abstract}
Stubby root nematodes (SRN) are important plant parasites infecting many crops and widely distributed in many regions of the United States. SRN transmit Tobacco rattle virus, which causes potato corky ringspot disease, thereby having a significant economic impact on the potato industry. In 2015 to 2017, 184 soil samples and 16 nematode suspensions from North Dakota, Minnesota, Idaho, Oregon, Washington, South Carolina, North Carolina, and Florida were assayed for the presence of SRN. SRN were found in 106 soil samples with population densities of 10 to 320 SRN per $200 \mathrm{~g}$ of soil and in eight of the nematode suspensions. Sequencing of ribosomal DNA (rDNA) or speciesspecific polymerase chain reaction assays revealed the presence of four SRN species, including Paratrichodorus allius, P. minor, P. porosus, and Trichodorus obtusus. Accordingly, their rDNA sequences were

characterized by analyzing D2-D3 of $28 \mathrm{~S}$ rDNA, $18 \mathrm{~S}$ rDNA, and internal transcribed spacer (ITS) rDNA obtained in this study and retrieved from GenBank. Both intra- and interspecies variations were higher in ITS rDNA than $18 \mathrm{~S}$ rDNA and D2-D3 of 28S rDNA. Based on phylogenetic analysis, the four SRN species formed a monophyletic group, with $P$. allius more closely related to $P$. porosus than $P$. minor and T. obtusus. Indel variation of ITS2 rDNA was present in $P$. allius populations from the same geographic regions. This study documented the occurrence of SRN species across multiple states. The intra- and interspecies genetic diversity of rDNA in this study will provide more information for understanding the evolutionary relationships of SRN and will be valuable for future studies of SRN species identification and management.
\end{abstract}

Stubby root nematodes (SRN) belonging to the family Trichodoridae are plant-ectoparasitic and comprise six genera: Trichodorus Cobb, 1913; Paratrichodorus Siddiqi, 1974; Nanidorus Siddiqi, 1974; Monotrichodorus Andrássy, 1976; Allotrichodorus Rodriguez Montessoro, Sher and Siddiqi, 1978; and Ecuadorus Siddiqi, 2002 (Heydari et al. 2014). It has been reported that the Trichodorus and Paratrichodorus genera have the largest number of species and are distributed worldwide (Taylor and Brown 1997). Among them, 13 species transmit plant viruses (mainly Tobacco rattle virus [TRV], Pea-early browning virus, and Pepper ringspot virus) and cause severe economic damage on crops (Decraemer and Robbins 2007). Therefore, it is important to identify the SRN species present in crop fields to optimize nematode management strategies. Even though the identification of nematode species can be accomplished by morphometric measurements (Decraemer and Baujard 1998), it is often difficult to differentiate closely related species due to limited diagnostic characteristics and minor morphological differences (Riga et al. 2007). Consequently, molecular approaches for identifying SRN species were developed, such as polymerase chain reaction (PCR) restriction fragment length polymorphism (RFLP), speciesspecific PCR, real-time PCR, and DNA sequencing (Boutsika et al. 2004c; Duarte et al. 2011; Holeva et al. 2006; Huang et al. 2017a,

${ }^{\dagger}$ Corresponding author: Guiping Yan; E-mail: guiping.yan@ndsu.edu

Funding: This research was supported by United States Department of Agriculture (USDA)-National Institute of Food and Agriculture (NIFA)-Special Crop Research Initiative award number 2014-51181-22373 and USDANIFA Hatch Multistate project number ND02233.

*The $\boldsymbol{e}$-Xtra logo stands for "electronic extra" and indicates that three supplementary figures and two supplementary tables are published online.

Accepted for publication 16 April 2018.

(c) 2018 The American Phytopathological Society b; Kumari and Subbotin 2012; Riga et al. 2007). However, in contrast to other well-studied plant-parasitic nematodes having large sequence databases such as Pratylenchus spp. (Janssen et al. 2017) and Meloidogyne spp. (Ye et al. 2015b), limited sequence information is available for the SRN.

In the past 20 years, a few studies reported the molecular characterization of SRN and genetic variability using ribosomal DNA (rDNA) and other genes (Blaxter et al. 1998; Boutsika et al. 2004b; Duarte et al. 2010; Kumari and Subbotin 2012; Riga et al. 2007; Shaver et al. 2016; Van Megen et al. 2009). Boutsika et al. (2004b) characterized the rDNA sequences of $18 \mathrm{~S}, 5.8 \mathrm{~S}, 28 \mathrm{~S}$, internal transcribed spacer (ITS) 1 and ITS2 regions of Paratrichodorus macrostylus, P. pachydermus, Trichodorus primitivus, and $T$. similis by analyzing sequence length; nucleotide GC\%; similarity; nucleotide substitutions, insertions, and deletions; number of repeats; and phylogenetic relations. Duarte et al. (2010) analyzed the sequences of 18S rDNA from 12 SRN species, including two Nanidorus spp., seven Paratrichodorus spp., and three Trichodorus spp. Subsequently, Kumari and Subbotin (2012) summarized the intraspecific sequence diversity of available $28 \mathrm{~S}$ rDNA and 18S rDNA sequences of 22 SRN species. Most recently, the genetic structure and haplotype diversity of $T$. obtusus populations from South Carolina and Florida were analyzed using18S rDNA and the cytochrome oxidase I (COI) gene (Shaver et al. 2016). Based on the rDNA sequence diversity information, PCRRFLP was used by Boutsika et al. (2004c) and Duarte et al. (2011) to differentiate Trichodoridae species. Similarly, Huang et al. (2017a, b) developed a species-specific PCR and real-time PCR for identification and quantification of $P$. allius according to the rDNA diversity across SRN species.

Unfortunately, many species remain uncharacterized at the molecular level due to lack of corresponding sequence information. Limited research has been conducted for the molecular characterization of SRN P. allius, an economically important virus vector that is widely distributed in multiple states of the United States (Kirk et al. 2008; Lopez-Nicora et al. 2014; Mojtahedi et al. 2000; Yan et al. 2016a,b). Excluding the DNA sequences submitted by our research group (Huang et al. 2017b; Yan et al. 2016a,b), there are only 
six DNA sequences of $P$. allius available in GenBank. The limited genome sequence information and high sequence divergence have made it challenging to develop a nucleic acid-based assay for the detection and identification of this nematode species. Thus, it is necessary to develop sequence information to better characterize populations of SRN from different geographic regions to better understand their genetic diversity and distribution patterns.

This study characterized nematodes collected from eight states in the United States, including North Dakota, Minnesota, Oregon, Idaho, Washington, North Carolina, South Carolina, and Florida, which historically had SRN infestation (Huang et al. 2017a,b; Kirk et al. 2008; Mojtahedi et al. 2000; Shaver et al. 2016; Yan et al. 2016a,b; Ye et al. 2015a). The main objectives of this study were to (i) determine the presence of SRN and determine their population densities, (ii) identify species of SRN by rDNA sequencing or species-specific PCR, (iii) investigate the intra- and interspecies divergence of rDNA within and among populations from different geographic regions (e.g., states), and (iv) determine their evolutionary relationship by phylogenetic analysis. These findings will expand our knowledge of the species diversity, distribution, DNA sequence divergence, and molecular diagnosis on SRN. This is the first study of molecular characterization of $P$. allius populations from diverse geographic regions.

\section{Materials and Methods}

Nematode sample collection and density determination. In 2015 to 2017, we collected 138 soil samples from North Dakota and 5 soil samples from Minnesota fields that were planted to potato, sugarbeet, or field pea. Upon request, we received 57 samples from other states historically having SRN, including 21 soil samples from Idaho, 13 from Oregon, 2 from Washington, 3 from Florida, and 2 from South Carolina, and 16 nematode suspensions from North Carolina collected from potato, grass, spinach, and soybean fields (Table 1; Supplementary Table S1). For the nematode extraction, big soil clumps were crushed by hand, each soil sample was mixed thoroughly, and $200 \mathrm{~g}$ of soil was subsampled. Nematodes were extracted from soil using sieving and decanting and sugar centrifugal flotation methods, as described by Plaisance and Yan (2015). According to the typical morphological features of SRN, including a solid and curved onchiostyle and a cigar-shaped body (Decraemer and Baujard 1998), SRN were identified and their population density (number of nematodes per $200 \mathrm{~g}$ of soil) was estimated by the formula (number of SRN per milliliter of suspension) $\times$ (total volume of the nematode suspension from $200 \mathrm{~g}$ of soil). The counting was performed on a nematode counting slide (Chalex Co., Portland, OR) under a dissecting microscope (Zeiss Stemi 305 compact stereo microscope; Zeiss, Thornwood, NY), as described by Plaisance and Yan (2015). SRN from each positive sample were arbitrarily sampled to represent an independent SRN population to be used for further experiments.

DNA extraction. Nematode DNA was extracted from individuals using the Proteinase K method, as described by Kumari and Subbotin (2012). Briefly, a single nematode individual was transferred into $15 \mu$ l of double-distilled (dd) $\mathrm{H}_{2} \mathrm{O}$ on a concavity slide (Labscientific Inc., Livingston, $\mathrm{NJ}$ ) and chopped into pieces under the dissecting microscope (Zeiss Stemi 305 compact stereo microscope; Zeiss). A suspension $(10 \mu \mathrm{l})$ containing nematode pieces was pipetted into a $0.5-\mathrm{ml}$ microcentrifuge tube containing $2 \mu \mathrm{l}$ of $10 \times$ PCR buffer (Roche, Mannheim, Germany), $2 \mu \mathrm{l}$ of Proteinase K $(600 \mu \mathrm{g} / \mathrm{ml})$, and $6 \mu \mathrm{l}$ of $\mathrm{ddH}_{2} \mathrm{O}$. The tubes were incubated at $65^{\circ} \mathrm{C}$ for $1 \mathrm{~h}$ after $20 \mathrm{~min}$ at $-20^{\circ} \mathrm{C}$. To eliminate the activity of Proteinase K, the DNA extracts were further incubated at $95^{\circ} \mathrm{C}$ for $10 \mathrm{~min}$. Finally, after cooling to room temperature, DNA extracts were spun down to the bottom of the tubes at $10,000 \mathrm{rpm}$ for $2 \mathrm{~min}$. The resulting $20-\mu \mathrm{l}$ DNA extracts were stored at $-20^{\circ} \mathrm{C}$ for subsequent experiments. DNA extractions were performed from three individuals of each population as replicates.

PCR amplification using universal primers and DNA sequencing. In this study, the rDNA of the D2-D3 of 28S, 18S, and ITS regions were amplified and sequenced. All PCR amplifications were run on the Bio-Rad T100 Thermal Cycler (Bio-Rad Laboratories, Hercules, CA).

Table 1. Sampling, nematode species, and population densities of stubby root nematodes used in this study

\begin{tabular}{|c|c|c|c|c|c|c|}
\hline States $^{w}$ & $\begin{array}{l}\text { Date received or } \\
\text { sampling }\end{array}$ & $\begin{array}{c}\text { Number of samples } \\
\text { collected }\end{array}$ & $\begin{array}{c}\text { Number of samples } \\
\text { having SRN }\end{array}$ & $\begin{array}{c}\text { Density per } 200 \mathrm{~g} \\
\text { of soil }\end{array}$ & Species identity $^{\mathrm{y}}$ & Identification method $^{\mathbf{z}}$ \\
\hline North Dakota* & April 2016 & 60 & 23 & $15-135$ & P. allius (15) & Species-specific PCR \\
\hline North Dakota & May 2016 & 2 & 2 & $25-250$ & P. allius (2) & Sequencing \\
\hline North Dakota & September 2016 & 5 & 4 & $10-90$ & $P$. allius (3) & Species-specific PCR \\
\hline North Dakota & October 2016 & 40 & 23 & $20-250$ & P. allius (14) & Species-specific PCR \\
\hline North Dakota & November 2016 & 3 & 2 & $10-20$ & P. allius (2) & Species-specific PCR \\
\hline North Dakota & May 2017 & 28 & 18 & $15-100$ & P. allius (8) & $\begin{array}{l}\text { Sequencing (2), species- } \\
\text { specific PCR (6) }\end{array}$ \\
\hline Minnesota* & May 2016 & 2 & 1 & 15 & P. allius (1) & Species-specific PCR \\
\hline Minnesota & June 2016 & 3 & 2 & $20-50$ & P. allius (2) & Species-specific PCR \\
\hline Idaho & October 2015 & 6 & 6 & $10-170$ & P. allius (6) & $\begin{array}{l}\text { Sequencing (4), species- } \\
\text { specific PCR (2) }\end{array}$ \\
\hline Idaho & April 2016 & 1 & 1 & 30 & P. allius (1) & Species-specific PCR \\
\hline Idaho & October 2016 & 14 & 12 & $15-240$ & P. allius (12) & Species-specific PCR \\
\hline Oregon & May 2015 & 2 & 2 & $105-300$ & P. allius (2) & Sequencing \\
\hline Oregon & November 2016 & 3 & 2 & $20-75$ & P. allius (2) & Species-specific PCR \\
\hline Oregon & December 2016 & 8 & 1 & 25 & P. allius (1) & Species-specific PCR \\
\hline Washington & November 2015 & 2 & 2 & $20-35$ & P. allius (2) & Sequencing \\
\hline South Carolina* & December 2015 & 2 & 2 & $170-320$ & $\begin{array}{l}\text { P. porosus }(1) \\
\text { T. obtusus }(1)\end{array}$ & Sequencing \\
\hline Florida* & April 2016 & 3 & 3 & $40-60$ & T. obtusus (3) & Sequencing \\
\hline North Carolina* & May 2016 & 16 & 8 & $\ldots$ & $\begin{array}{l}\text { P. porosus }(2), \\
\text { P. minor }(6)\end{array}$ & Sequencing \\
\hline
\end{tabular}

${ }^{\mathrm{w}}$ Asterisks $(*)$ indicate two populations of Paratrichodorus allius (one from North Dakota and one from Minnesota), two populations of P. porosus (one from North Carolina and one from South Carolina), one population of P. minor (from North Carolina), and two populations of Trichodorus obtusus (one from Florida and one from South Carolina) that were previously identified and served as control nematode DNA in another publication (Huang et al. 2017a).

${ }^{x} \mathrm{SRN}=$ stubby root nematodes.

y Numbers in parentheses indicate the number of populations that were identified to species.

${ }^{\mathrm{z}}$ Species were identified by sequencing of $18 \mathrm{~S}$ ribosomal DNA (rDNA), D2-D3 of $28 \mathrm{~S}$ rDNA, or internal transcribed spacer rDNA or $P$. allius species-specific polymerase chain reaction (PCR), as described by Huang et al. (2017b). Numbers within parentheses indicate the number of identified populations using the corresponding method. 
For D2-D3 of 28S rDNA, PCR amplification with primers D2A (5'-ACAAGTACCGTGAGGGAAAGTTG-3')/D3B (5'-TCGGAA GGAACCAGCTACTA-3') (De Ley et al. 1999) was performed in a $25-\mu 1$ reaction volume comprising $2.0 \mu \mathrm{l}$ of DNA extracts, $0.5 \mu \mathrm{M}$ each forward and reverse primer, $0.2 \mathrm{mM} \mathrm{dNTP}, 1 \times \mathrm{PCR}$ buffer (with $1.5 \mathrm{mM} \mathrm{MgCl}_{2}$ ), and $0.75 \mathrm{U}$ of dNTPack Taq DNA Polymerase (Roche). The amplification conditions were $94^{\circ} \mathrm{C}$ for $2 \mathrm{~min}$; 40 cycles of $30 \mathrm{~s}$ at $94^{\circ} \mathrm{C}, 1 \mathrm{~min}$ at $55^{\circ} \mathrm{C}$, and $2 \mathrm{~min}$ at $72^{\circ} \mathrm{C}$; and a final extension for $7 \mathrm{~min}$ at $72^{\circ} \mathrm{C}$.

For partial $18 \mathrm{~S}$ rDNA, two segments were amplified with SSU (small subunit) primer sets SSUF18A (5'-AAAGATTAAGCCATG CATG-3')/SSU26R (5'-CATTCTTGGCAAATGCTTTCG-3') (Floyd et al. 2002) and 18S965 (5'-GGCGATCAGATACCGCCCTAGTT$\left.3^{\prime}\right) / 18$ S18P (5'-TGATCCWKCYGCAGGTTCAC-3') (De Ley et al. 2002; Mullin et al. 2005). The PCR was accomplished in a $25-\mu l$ volume containing $1.5 \mu \mathrm{l}$ of DNA extracts, $0.3 \mu \mathrm{M}$ each forward and reverse primer, $0.2 \mathrm{mM}$ dNTP, $2.5 \mathrm{mM} \mathrm{MgCl}_{2}, 1 \times$ Colorless GoTaq Flexi Buffer, and 1.0 U of GoTaq Flexi DNA Polymerase (Promega Corp., Madison, WI). The amplification conditions were $94^{\circ} \mathrm{C}$ for $3 \mathrm{~min} ; 35$ cycles of $30 \mathrm{~s}$ at $94^{\circ} \mathrm{C}, 30 \mathrm{~s}$ at $53^{\circ} \mathrm{C}$, and $1.5 \mathrm{~min}$ at $72^{\circ} \mathrm{C}$; and a final extension of $10 \mathrm{~min}$ at $72^{\circ} \mathrm{C}$.

For ITS1 rDNA, PCR amplification with primers BL18 (5'CCCGTCGMTACTACCGATT-3')/5818 (5'-ACGARCCGAGTGATCCAC$3^{\prime}$ ) (Boutsika et al. 2004b) was performed in a 20- $\mu$ l reaction volume containing $1.0 \mu \mathrm{l}$ of DNA extracts, $0.2 \mu \mathrm{M}$ each forward and reverse primer, $0.2 \mathrm{mM}$ dNTP, $1 \times$ PCR buffer (with $1.5 \mathrm{mM} \mathrm{MgCl}_{2}$ ), and $0.6 \mathrm{U}$ of dNTPack Taq DNA Polymerase (Roche). The amplification conditions were $94^{\circ} \mathrm{C}$ for $4 \mathrm{~min} ; 35$ cycles of $1 \mathrm{~min}$ at $94^{\circ} \mathrm{C}, 45 \mathrm{~s}$ at $58^{\circ} \mathrm{C}$, and $1 \mathrm{~min}$ at $72^{\circ} \mathrm{C}$; and a final extension for $10 \mathrm{~min}$ at $72^{\circ} \mathrm{C}$. For ITS rDNA, including ITS1, 5.8S, and ITS2 regions, PCR amplification with primers TW81 (5'-GTTTCCGTAGGTGAACCTGC$\left.3^{\prime}\right) /$ AB28 (5'-ATATGCTTAAGTTCAGCGGGT-3') (Joyce et al. 1994) was performed in a $20-\mu \mathrm{l}$ reaction volume containing $1.5 \mu \mathrm{l}$ of DNA extracts, $1 \mu \mathrm{M}$ each forward and reverse primer, $0.2 \mathrm{mM}$ dNTP, $2.0 \mathrm{mM} \mathrm{MgCl} 2$, $1 \times$ Colorless GoTaq Flexi PCR buffer, and $1.0 \mathrm{U}$ of GoTaq Flexi DNA Polymerase (Promega Corp.). The amplification conditions were $94^{\circ} \mathrm{C}$ for $3 \mathrm{~min} ; 35$ cycles of $50 \mathrm{~s}$ at $94^{\circ} \mathrm{C}$, $50 \mathrm{~s}$ at $58^{\circ} \mathrm{C}$, and $1.5 \mathrm{~min}$ at $72^{\circ} \mathrm{C}$; and a final extension of $10 \mathrm{~min}$ at $72^{\circ} \mathrm{C}$.

To check the products from PCR amplification, the mixture of $0.5 \mu \mathrm{l}$ of $6 \times$ loading dye (Promega Corp.) and $2 \mu \mathrm{l}$ of PCR products was loaded in a $1.5 \%$ agarose gel containing ethidium bromide $(0.5$ $\mu \mathrm{g} / \mathrm{ml}$ ) and run for 30 mins at $90 \mathrm{~V}$, using Owl EasyCast Wide-Format Horizontal Electrophoresis Systems (Model D3-14 System; ThermoFisher Scientific, Pittsburgh). The banding pattern was visualized under UV light and recorded using the AlphaImager Gel Documentation System (Proteinsimple Inc., Santa Clara, CA). For direct sequencing, samples were prepared by purification of PCR products using the E.Z.N.A Cycle Pure Kit (Omega Biotek Inc., Doraville, GA). For cloning and sequencing, purified PCR products were cloned using pGEM-T easy vector system (Promega Corp.) with the protocol recommended by the manufacturer. Plasmid DNA was extracted from positive colonies using the E.Z.N.A Plasmid Mini Kit I (Omega Biotek Inc.) with the protocol recommended by the manufacturer. Nine plasmid DNA generated from three clones from three individual nematode DNA extracts were subjected for DNA sequencing. The sequencing process was performed by GenScript Corporation (Piscataway, NJ).

Sequence analysis. DNA sequences were edited by EditSeq module of DNASTAR software package (Lasergene, Madison, WI) and vector sequence and messy regions were removed. Consensus nucleotide sequences were obtained by alignment of edited nucleotide sequences from three individuals of a population using ClustalX software under default parameter settings (Thompson et al. 1997). Due to the overlapping of sequenced rDNA segments (Supplementary Fig. S1), sequences were assembled and each portion of rDNA (18S, ITS1, 5.8S, and ITS2) was defined using comparative strategy based on sequence information from other SRN species. The boundaries of 18S, ITS1, 5.8S, and ITS2 regions were determined by comparison of the aligned sequence with previously published sequences of P. macrostylus (accession numbers: AJ439507, AJ439512, AJ439517, and AJ439522), P. pachydermuns (accession numbers: AJ439508, AJ439513, AJ439518, and AJ439523), T. primitivus (accession numbers: AJ439509, AJ439514, AJ439519, and AJ439524), and T. similis (accession numbers: AJ439510, AJ439515, AJ439520, and AJ439525) (Boutsika et al. 2004b). For sequence divergence analysis, corresponding rDNA sequences of identified SRN species were retrieved from GenBank (Supplementary Table S2), and the nucleotide length, percentage of variation, and number of insertions or deletions, transitions, and transversions of intra- and interspecies were analyzed by the ClustalW method using the MegAlign module of DNASTAR software package.

Species identification by comparative sequence analysis and species-specific PCR. For species identification, at least one population from each geographic region was sequenced in genomic regions of D2-D3 of 28S rDNA, 18S rDNA, or ITS rDNA. Using obtained rDNA sequences as query sequence, a BlastN search against the database Nucleotide collection (nr/nt) was performed online at https:// blast.ncbi.nlm.nih.gov/Blast.cgi, with the program selection of Megablast, a program intended for comparing a query to closely related sequences. The species of top hits with an E-value of 0 and highest sequence identity were considered to be the candidate species of query sequences, as recommended by statistics based on the sequences alignment (Altschul et al. 1990). After comprehensive consideration of BlastN results generated from sequences of D2-D3 of 28S rDNA, 18S rDNA, and ITS rDNA, the species identity was defined. Meanwhile, the species-specific PCR was performed to determine $P$. allius in other populations isolated from the geographic regions infested by this species based on the species identification using sequencing information. As described by Huang et al. (2017b), PCR was accomplished in a total volume of $20 \mu \mathrm{l}$, including $1.0 \mu \mathrm{l}$ of DNA, $0.4 \mu \mathrm{l}$ of dNTP mixture $(10 \mathrm{mM}), 1.2 \mu \mathrm{l}$ of $\mathrm{MgCl}_{2}$ (25 mM), $0.5 \mu$ l each of $P$. allius-specific primers PaF11 $(10 \mu \mathrm{M})$ and PaR12 $(10 \mu \mathrm{M}), 4 \mu \mathrm{l}$ of $5 \times$ Green GoTaq Flexi buffer, $0.2 \mu \mathrm{l}$ of GoTaq Flexi DNA Polymerase $(5 \mathrm{U} / \mu \mathrm{l})$ (Promega Corp.), and $12.2 \mu \mathrm{l}$ of sterilized $\mathrm{ddH}_{2} \mathrm{O}$. The PCR was performed on a Bio-Rad T100 Thermal Cycler (Bio-Rad Laboratories) under the following conditions: $94^{\circ} \mathrm{C}$ for $3 \mathrm{~min} ; 35$ cycles of $94^{\circ} \mathrm{C}$ for $40 \mathrm{~s}, 60^{\circ} \mathrm{C}$ for $50 \mathrm{~s}$, and $72^{\circ} \mathrm{C}$ for $1 \mathrm{~min}$; and $72^{\circ} \mathrm{C}$ for $10 \mathrm{~min}$. The template DNA was extracted from single nematodes and at least three DNA samples from each population were used in the PCR. The PCR products were observed on the $2.5 \%$ agarose gel after electrophoresis at $120 \mathrm{~V}$ for $30 \mathrm{~min}$.

Phylogenetic analysis. Phylogenetic relationships among SRN obtained in this study were analyzed by comparing with reference sequences from GenBank using maximum-likelihood (ML) trees based on 28S, 18S, and ITS rDNA that were constructed using MEGA7 (Kumar et al. 2016). First, the alignment of corresponding sequences (obtained in this study and retrieved from the National Center for Biotechnology Information nucleotide database) was performed by MUSCLE (v3.8.31) with default settings for highest accuracy. The gaps and missing data were completely removed. Accordingly, the Tamura-Nei substitution model was selected using $\gamma$ distributed with invariant sites and five $\gamma$-distributed rate categories to account for rates and patterns. Finally, the phylogeny trees were constructed using the ML method. Bootstrap support for trees was generated with 1,000 replicate searches.

\section{Results}

Population densities of SRN and species identification. Based on morphological characteristics of nematodes isolated from soil samples, SRN were identified in 72 of 138 soil samples from North Dakota, with densities ranging from 10 to 250 individuals per $200 \mathrm{~g}$ of soil; in 3 of 5 samples from Minnesota at 15 to 50 individuals per $200 \mathrm{~g}$ of soil; in 19 of 21 samples from Idaho at 10 to 240 individuals per $200 \mathrm{~g}$ of soil; in 5 of 13 samples from Oregon at 20 to 300 individuals per $200 \mathrm{~g}$ of soil; in both samples from Washington at 20 to 35 individuals per $200 \mathrm{~g}$ of soil; in both samples from South Carolina at 170 to 320 individuals per $200 \mathrm{~g}$ of soil; and in all 3 samples from Florida at 40 to 60 individuals per $200 \mathrm{~g}$ of soil (Table 1). 
Additionally, SRN were found in 8 of 16 nematode suspensions from North Carolina. Females and juveniles were found in all SRN populations whereas males were found only in three populations from Florida and one population from South Carolina.

Species-specific PCR identified SRN populations of 40 soil samples as $P$. allius, in addition to four SRN populations identified as $P$. allius by sequencing of D2-D3 of 28S rDNA, $18 \mathrm{~S}$ rDNA, and ITS rDNA in North Dakota and Minnesota (Table 1). Sequencing of these genomic regions was used to identify SRN populations from six other states to species. The BlastN results using the D2-D3 of 28S rDNA, 18S rDNA, or ITS rDNA sequences suggested that four SRN species were present, including $P$. allius, $P$. minor, $P$. porosus, and $T$. obtusus (Table 1). As a result, P. allius was detected in two soil samples from Washington, two soil samples from Oregon, and four soil samples from Idaho; $P$. porosus was detected in one soil sample from South Carolina and two samples from North Carolina; $P$. minor in six samples from North Carolina; and T. obtusus in one soil sample from South Carolina and three soil samples from Florida. Noticeably, males were only observed in populations of $T$. obtusus. Subsequent soil samples received from the states known to have $P$. allius were subjected to the species-specific PCR developed by Huang et al. (2017b) and, consequently, $P$. allius was detected in 3 additional soil samples from Oregon and 15 soil samples from Idaho. This indicated that the species-specific PCR developed using specimens collected from Minnesota and North Dakota is also able to specifically detect $P$. allius in soils collected from other states.

Intra- and interspecies genetic diversity of $P$. allius, $P$. minor, $P$. porosus, and T. obtusus. Eight populations of $P$. allius (two from North Dakota, two from Minnesota, one from Washington, one from Oregon, and two from Idaho), two populations of $P$. porosus (one from South Carolina and one from North Carolina), one population of $P$. minor (from North Carolina), and two populations of T. obtusus (one from South Carolina and one from Florida) were selected as representatives, considering the geographic region and the D2-D3 of 28S rDNA and ITS1 rDNA sequence similarity within species (Table 2). According to the banding pattern of PCR products in the agarose gel, no visible difference of the length of $28 \mathrm{~S}$ rDNA and two segments of $18 \mathrm{~S}$ rDNA was observed among species (data not shown). By contrast, obvious variation of the length of ITS1 rDNA (amplified by primer set BL58/5818) was observed among species (Fig. 1). It is noted that one population of $P$. minor from North Carolina (NC-34546) generated a shorter length of PCR products of ITS1 rDNA than other $P$. minor populations (such as NC-34538), revealing the existence of sequence diversity of this species (Fig. 1).

The length of D2-D3 of 28S rDNA ranged from 724 to $799 \mathrm{bp}$ (Table 2). According to the BlastN search, 43 sequences of D2-D3 of $28 \mathrm{~S}$ rDNA, including 16 sequences from $P$. allius, 11 sequences from $P$. minor, 19 sequences from $P$. porosus, and 1 sequence from T. obtusus, were retrieved from GenBank for sequence variation and phylogenetic analysis. The sequence variations within species were $P$. allius, 0 to $0.8 \%$ (0 to 8 nucleotides [nt]); $P$. minor, 0 to $1.2 \%$ (0 to $12 \mathrm{nt}$ ); $P$. porosus, 0 to $0.6 \%$ (0 to $16 \mathrm{nt}$ ); and T. obtusus, 0 to $1.1 \%$ (0 to $9 \mathrm{nt})$.

The length of nucleotides in 18S rDNA partial-1 and 18S rDNA partial-2 ranged from 821 to 919 and 760 to $805 \mathrm{bp}$, respectively. According to the BlastN search, 69 sequences of $18 \mathrm{~S}$ rDNA, including 8 sequences from $P$. allius, 24 sequences from $P$. minor, 30 sequences from $P$. porosus, and s7 sequences from $T$. obtusus, were retrieved from GenBank for sequence variation and phylogenetic analysis. The variations of conserved sequences of $18 \mathrm{~S}$ rDNA partial-1 within species were $P$. allius, 0 to $5.4 \%$ (0 to $13 \mathrm{nt}$ ); $P$. $m i$ nor, 0 to $1.5 \%$ (0 to $9 \mathrm{nt}) ; P$. porosus, 0 to $6.5 \%$ (0 to $70 \mathrm{nt})$; and T. obtusus, 0 to $0.6 \%$ (0 to $2 \mathrm{nt}$ ). Comparably, the variations of conserved sequences of $18 \mathrm{~S}$ rDNA partial-2 (assembled) within species were $P$. allius, 0 to $1.9 \%$ (0 to $17 \mathrm{nt}$ ); $P$. minor, 0 to $1.4 \%$ (0 to $23 \mathrm{nt}$ ); P. porosus, 0 to $7.9 \%$ (0 to $56 \mathrm{nt}$ ); and $T$. obtusus, 0 to $0 \%$ (0 nt).

The segment of ITS1 rDNA was successfully amplified by PCR with primer set BL18/5818 from all four SRN species. However, the primer set TW81/AB28 only amplified ITS rDNA consisting of full sequences of ITS1 rDNA, 5.8S rDNA, and ITS2 rDNA using DNA of $P$. allius but not DNA of P. minor, P. porosus, and T. obtusus. Therefore, 5.8S rDNA and ITS2 rDNA were only obtained in $P$. allius. According to the PCR products amplified by BL18/5818, the length, including partial 18S rDNA, ITS1 rDNA, and partial 5.8S rDNA, varied significantly among species (Fig. 1). Particularly, the ITS1 rDNA in P. minor (>1,348 bp) and T. obtusus (>968 bp) was significantly longer than in $P$. allius (634 to $638 \mathrm{bp}$ ) and $P$. porosus (466 bp) (Table 2). Analyzing with 44 other sequences of ITS1 rDNA from GenBank (18 sequences from $P$. allius, 9 from $P$. minor, and 17 from $P$. porosus), the variation of conserved sequences within species were $P$. allius, 0 to $3.1 \%$ (0 to $31 \mathrm{nt}$ ); $P$. minor, 0 to $4.4 \%$ (0 to $94 \mathrm{nt})$; and $P$. porosus, 0 to $0.8 \%$ (0 to $9 \mathrm{nt})$. No other ITS1 rDNA of $T$. obtusus was retrieved from GenBank and the variation of two populations of $T$. obtusus ITS1 rDNA obtained in this study was 0 to $3.4 \%$ (0 to $51 \mathrm{nt}$ ). For $5.8 \mathrm{~S}$ rDNA and ITS2 rDNA sequences obtained exclusively in $P$. allius in this study, alignments showed that the eight sequences of $5.8 \mathrm{~S}$ rDNA were identical, with a length of $158 \mathrm{bp}$. Distinguished insertions or deletions were found in the ITS2 rDNA of $P$. allius (Fig. 2; Table 3), which is different from other regions of rDNA having substituted nucleotides.

Phylogenetic relationships of $P$. allius, $P$. minor, $P$. porosus, and T. obtusus. ML phylogenetic trees were constructed independently using sequences of 28S rDNA, 18S rDNA partial-1, 18 rDNA partial-2, ITS1 rDNA, and ITS2 rDNA. For the ML tree construction, the identical sequences retrieved from GenBank that were obtained from the same species within the same geographic region were removed. The resulting ML trees revealed four distinct clusters and each cluster harbored one SRN species. As an exception, $P$. porosus

Table 2. Lengths of sequences of $18 \mathrm{~S}$ ribosomal DNA (rDNA), $28 \mathrm{~S}$ rDNA, and internal transcribed spacer (ITS) rDNA from Paratrichodorus allius, $P$. minor, P. porosus, and Trichodorus obtusus obtained in this study ${ }^{\mathrm{y}}$

\begin{tabular}{|c|c|c|c|c|c|c|c|}
\hline Species & Population ID & D2-D3 of $28 S$ rRNA & 18S rRNA partial-1 & 18S rRNA partial-2 & ITS1 rDNA & 5.8S rRNA & ITS2 rDNA \\
\hline \multirow[t]{8}{*}{ P. allius } & ND-1 & $799 *$ & $919^{*}$ & 805 & 638 & 158 & $397(\mathrm{p})$ \\
\hline & ND-2 & 781 & 888 & 795 & 634 & 158 & 416 \\
\hline & MN-1 & $738^{*}$ & $846^{*}$ & 760 & 636 & 158 & $345(\mathrm{p})$ \\
\hline & $\mathrm{MN}-2$ & $799^{z}$ & 831 & 766 & $634^{z}$ & $158^{\mathrm{z}}$ & $416^{z}$ \\
\hline & WA & 737 & 883 & 787 & 638 & 158 & 429 \\
\hline & OR & 727 & 854 & 765 & 634 & 158 & $345(\mathrm{p})$ \\
\hline & ID-1 & 739 & 893 & 787 & 638 & 158 & $419(\mathrm{p})$ \\
\hline & ID-2 & 724 & 851 & 787 & 634 & 158 & $348(\mathrm{p})$ \\
\hline \multirow[t]{2}{*}{ T. obtusus } & FL & 729 & 860 & 787 & $968(\mathrm{p})$ & - & - \\
\hline & SC-G & 776 & 822 & 787 & $910(\mathrm{p})$ & - & - \\
\hline \multirow[t]{2}{*}{ P. porosus } & SC-C & 763 & 829 & 771 & 466 & $21(\mathrm{p})$ & - \\
\hline & NC-33613 & 744 & 897 & 787 & 466 & $23(\mathrm{p})$ & - \\
\hline P. minor & NC-34212 & 785 & 821 & 785 & $1,348(\mathrm{p})$ & - & - \\
\hline
\end{tabular}

${ }^{y}$ Asterisks $(*)$ indicate that the sequences were previously reported and corresponding GenBank accession numbers were KU094057 (799bp), KU094058 (919bp), KT892732 (738bp), and KT892733 (846bp); (p) indicates partial sequences of ITS rDNA; and - indicates that sequence information is not available. ${ }^{\mathrm{z}}$ Sequences were obtained by cloning and sequencing. 
sequences were clustered into the species of $P$. minor in the two ML trees constructed by $18 \mathrm{~S}$ rDNA sequences (Supplementary Fig. S2). The monophyletic relationship was found among four species in ML trees (Figs. 3, 4, and 5). Among the four species, $P$. allius and $P$. porosus are more closely related to each other than to the other two species. Within the species of $P$. allius, the eight populations collected in this study can be subgrouped into two clusters, comprising $\mathrm{MN}-1, \mathrm{MN}-2$, ND-2, ID-2, and OR in one cluster and ID-1, ND1, and WA in another cluster (Fig. 3 and Supplementary Fig. S3). Hence, the genetic diversity is not well correlated with the geographic distribution, indicating independent migrants of $P$. allius. Compared with the reported sequences in GenBank, $P$. porosus and $P$. minor collected in this study from the United States are also closely related to those from other countries such as China and Japan (Figs. 3, 4, and 5).

\section{Discussion}

This research evaluated the presence of SRN and identified their species in soil samples or nematode suspensions collected from multiple states in the United States. The sequences of rDNA were characterized in those SRN species and their phylogenetic relationships were established.

SRN species $P$. allius has been previously reported in the states of North Dakota and Minnesota (Yan et al. 2016a,b). Upon request, soil samples were collected from multiple states where the presence of SRN has been reported, including Idaho, Oregon, Washington, Florida, South Carolina, and North Carolina (Riga and Neilson 2005; Ye et al. 2015a; Zeng et al. 2012). Using microscopic observation and molecular identification referring to rDNA sequence characterization and species-specific PCR, the present study identified the species as $P$. allius, $P$. minor, $P$. porosus, and $T$. obtusus. It was found that $P$. allius was presented in 47 of 75 soil samples positively infested by SRN in North Dakota and Minnesota. Similarly, 26 soil samples having SRN from the states of Idaho, Oregon, and Washington were demonstrated to be infested by $P$. allius as well. However, even though $P$. allius was reported in the states of North Carolina and South Carolina (Zeng et al. 2012), we did not detect this species in two soil samples from South Carolina and eight nematode suspensions from North Carolina, positively having SRN. Instead, the species $P$. minor was exclusively found in six of eight nematode suspensions from North Carolina, which agreed with the conclusion that $P$. minor was the most prevalent SRN present in 16 counties in North Carolina (Zeng et al. 2012). No P. minor was found in the limited number of samples from other states even though this species was distributed in South Carolina, Oregon, Idaho, and Washington (CABI/EPPO 2002). The species P. porosus was reported in Florida, North Carolina, and South Carolina (CABI/EPPO 2009) and we found it in two nematode suspensions from North Carolina and
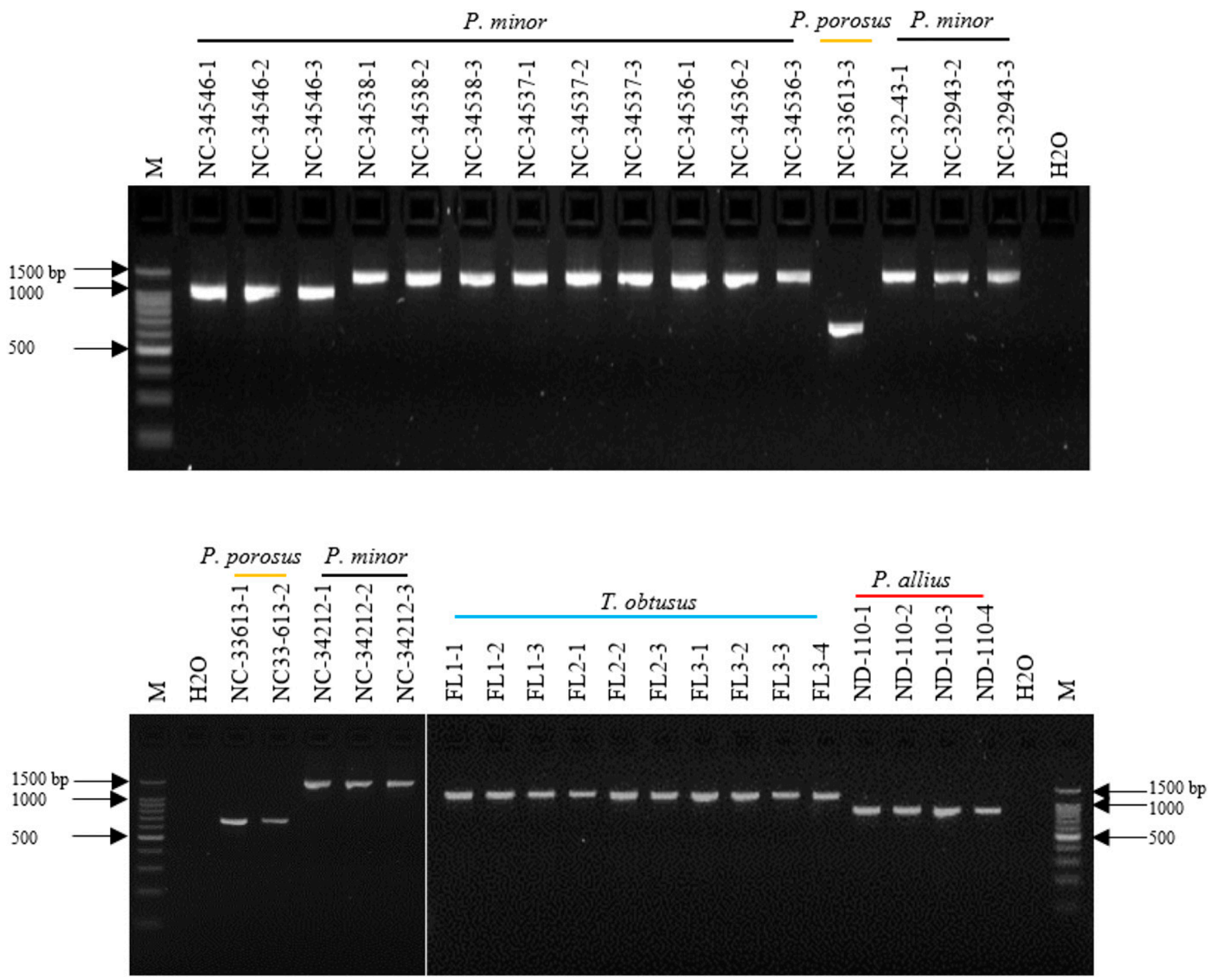

Fig. 1. An example of polymerase chain reaction (PCR) products of internal transcribe spacer 1 ribosomal DNA amplified by primer set BL18/5818 using nematode DNA extracted from individuals isolated from different states. Lane M: 100-bp DNA ladders (Promega Corp.). Lane $\mathrm{H}_{2} \mathrm{O}$ : PCR amplification using double-distilled $\mathrm{H}_{2} \mathrm{O}$ instead of DNA as a template. Other lane labels stand for state-population ID-replicates. Populations of NC-34546, NC-34538, NC-34537, NC-34536, NC-32943, and NC-34212 were Paratrichodorus minor. Population of NC-33613 was P. porosus. Populations of FL1, FL2, and FL3 were Trichodorus obtusus. Population of ND-110 was P. allius. 
one soil sample from South Carolina but not in the three soil samples from Florida. By contrast, the species T. obtusus was identified in all three samples from Florida and one sample from South Carolina. Compared with the other three SRN species, male adults were only observed in the species T. obtusus, which can be explained by the requirement of mating to produce offspring (Crow 2005). Additionally, $P$. allius-infested fields were planted with different crops, including potato, field pea, and sugarbeet, which is different than T. obtusus found in the grass-grown field, $P$. porosus in spinach and soybean fields, and $P$. minor found in a soybean field, indicating different preferences of host or crop by these four SRN species.

rDNA is widely used to analyze the molecular characterization of plant-parasitic nematodes and their polygenetic relations (Aleshin et al. 1998; Blaxter et al. 1998; Blaxter et al. 2005; Boutsika et al. 2004a,b; De Ley et al. 2002; Duarte et al. 2010; Holterman et al. 2006; Holterman et al. 2008; Lazarova et al. 2006; Neilson et al. 2004; Shaver et al. 2016; Subbotin et al. 2008; Waeyenberge et al. 2009). Commonly, there are three outcomes of the research based on molecular sequence analyses - evolutionary analysis, species taxonomic analysis, and synonyms clarification-providing information for quick molecular diagnosis. For instance, Boutsika et al. (2004a) clarified the synonymy of $P$. christiei (Allen, 1957) Siddiqi, 1974 with $P$. minor (Colbran, 1956) Siddiqi, 1974 (Nematoda, Triplonchida) based on sequence data obtained for the rDNA 18 S gene, whereas Duarte et al. (2010) accepted the genus Nanidorus as a valid genus separating from genus Paratrichodorus, according to the phylogenetic relationship inferred from 18S rRNA gene sequences. By using the ITS rDNA sequences of 20 different Pratylenchus spp., Waeyenberge et al. (2009) explored a duplex PCR to specifically identify Pratylenchus penetrans. In this study, we sequenced the D2-D3 of $28 \mathrm{~S}$ rDNA, two segments of $18 \mathrm{~S}$ rDNA, and ITS rDNA of eight Paratrichodorus allius populations, one $P$. minor population, two $P$. porosus populations, and two T. obtusus populations. The phylogenetic analyses using rDNA sequences obtained in this study and available sequences in GenBank yielded four notable groups associated with four species, supporting the species identity assigned by BlastN search. Consistent with the phylogenetic tree constructed by Duarte et al. (2010) and Kumari and Subbotin (2012) using 18S rDNA, a closer relationship between $P$. allius and $P$. porosus was found compared with Nanidorus minor ( $P$. minor in this study) and other Trichodorus spp., which was further demonstrated by additional analysis in this study using $28 \mathrm{~S}$ rDNA and ITS rDNA. Surprisingly, two isolates of $P$. porosus retrieved from GenBank were clustered with $P$. minor in the ML trees constructed based on $18 \mathrm{~S}$ rDNA sequences, which might be due to the inaccuracy of species identity reported in the GenBank database to some extent (Fig. 4).

Limited studies have been done regarding the genetic diversity of rDNA within species of SRN. One population of $P$. minor (NC34546 ), its species identity supported by $28 \mathrm{~S}$ rDNA (GenBank accession MG973084) and 18S rDNA (accession MG973085) sequences, has a shorter ITS1 rDNA sequence (accession MG973086) compared with five other populations (Fig. 1), which was caused by deletion (data not shown). However, this variation was not found in any other available ITS rDNA sequences in P. minor. Therefore, the rDNA sequences were not employed in the sequence divergence and phylogenetic analysis. More specimens need to be collected and further research needs to be conducted to confirm this unique deletion in $P$. minor. On the other hand, we expect that genetic diversity may be associated with geographic locations of plants and pathogens (Hagenblad et al. 2016; Wang et al. 2014). However, Shaver et al. (2016) found a strong and significant genetic differentiation between

Table 3. Number of insertions or deletions, transitions, and transversions in rDNA sequences of eight populations of Paratrichodorus allius collected from five states ${ }^{\mathrm{w}}$

\begin{tabular}{lcccccc}
\hline & $\begin{array}{c}\text { D2-D3 of } \\
\text { 28S } \\
\text { Variables }\end{array}$ & $\begin{array}{c}\text { 18S DNA } \\
\text { rDNA }\end{array}$ & $\begin{array}{c}\text { 18S DNA } \\
\text { partial-1 }\end{array}$ & $\begin{array}{c}\text { ITS1 } \\
\text { partial-2 }\end{array}$ & $\begin{array}{c}\text { r.8S } \\
\text { rDNA }\end{array}$ & $\begin{array}{r}\text { ITS2 } \\
\text { rDNA }\end{array}$ \\
\hline $\begin{array}{l}\text { Insertion or } \\
\text { reletions }\end{array}$ & 0 & 3 & 7 & 6 & 0 & 67 \\
Transitions $^{\mathrm{y}}$ & 3 & 6 & 2 & 16 & 0 & 12 \\
Transversions $^{\mathrm{z}}$ & 5 & 4 & 8 & 9 & 0 & 5 \\
\hline
\end{tabular}

${ }^{\mathrm{w}} \mathrm{rDNA}=$ ribosomal DNA and ITS $=$ internal transcribed spacer.

${ }^{x}$ Insertions or deletions refer to the additional or missing one nucleotide in a DNA sequence.

y Transitions refer to the changes from a purine to another purine $(A \leftrightarrow G)$ or a pyrimidine to another pyrimidine $(\mathrm{C} \leftrightarrow \mathrm{T})$ in a DNA sequence.

z Transversions refer to the substitution of a purine for a pyrimidine in a DNA sequence.

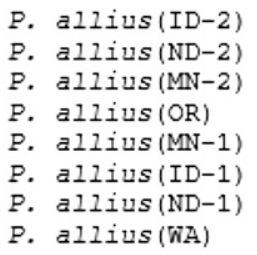

P. allius(ID-2)

P. allius (ND-2)

P. allius (MN-2)

P. allius (OR)

P. allius (MN-1)

P. allius (ID-1)

P. allius (ND-1)

P. allius (WA)

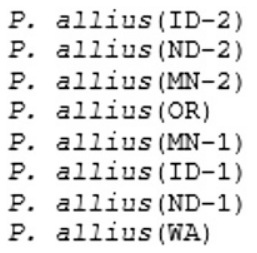

CAGTGAAAGCATATATCCTTGCTCGTTGACCCTGCTTA--GTCGAAGGGTTTT--CTTTC 56 CAGTGAAAGCATATATCCTTGCTCGTTGACCCTGCTTA--GTCGAAGGGTTTT--CTTTC 56 CAGTGAAAGCATATATCCTTGCTCGTTGACCCTGCTTA--GTCGAAGGGTTTT--CTTTC 56 CAGTGAAAGCATATATCCTTGCTCGTTGACCCTGCTTA--GTCGAAGGGTTTT--CTTTC 56 CAGTGAAAGCATATATCCTTGCTCGTTGACCCTGCTTA--GTCGAAGGGTTTT--CTTTC 56 CAGTGAAAGCATATATCCTTGCTCGTTGACCCTGCTTATAGTCGAAGGGTTTTGGCTTTC 60 CAGTGAAAGCATATATCCTTGCTCGTTGACCCTGCTTATAGTCGAAGGGTTTTGGCTTTC 60 CAGTGAAAGCATATATCCTTGCTCGTTGACCCTGCTTATAGTCGAAGGGTTTTGGCTTTC 60

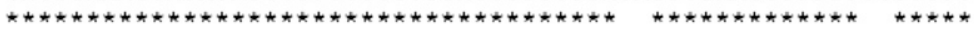

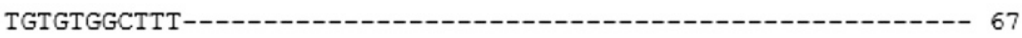
TGTGTGGCTTTGCGTGTCGAATCAACACGCTTGAATGGGCTCAGAAAG----CTCTTACT 112 TGTGTGGCTCTGCGTGTCGAATCAACACGCTTGAATGGGCTCAGAAAG----CTCTTACT 112

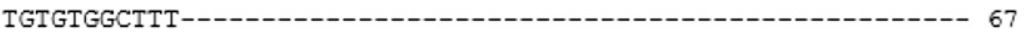

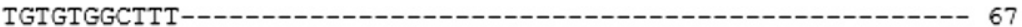
TGTGTGGCTCTGCGTGTCGAATCTACACGCTTGAATGGGCTCAGAAAGACAGTTTTTACT 120 TGTGTGGCTCTGCGTGTCGAATCTACACGCTTGAATGGGCTCAGAAAGACAGTTTTTACT 120 TGTGTGGCTCTGCGTGTCGAATCTACACGCTTGAATGGGCTCAGAAAGACAGTTTTTACT 120

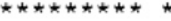

---------ACGCGTCGCTCATATACGCGTTCGAATAGGCTCAGTAAGGCCTTTACGGC 117 GTGTGGCTTTACGCGTCGCTCATATACGCGTTCGAATAGGCTCAGTAAGGCCTTTACGGC 172 GTGTGGCTTTACGCGTCGCTCATATACGCGTTCGAATAGGCTCAGTAAGGCCTTTACGGC 172 --------ACGCGTCGCTCATATACGCGTTCGAATAGGCTCAGTAAGGCCTTTACGGC 117 --------ACGCGTCGCTCATATACGCGTTCGAATAGGCTCAGTAAGGCCTTTACGGC 117 GTGTGGCCTTACGCGTCGCTAATATACGCGTTCGAATAGGCTCAGTAAGGCCTTTACGGC 180 GTGTGGCCTTACGCGTCGCTAATATACGCGTTCGAATAGGCTCAGTAAGGCCTTTACGGC 180 GTGTGGCCTTACGCGTCGCTCATATACGCGTTCGAATAGGCTCAGTAAGGCCCTTACGGC 180

Fig. 2. Partial alignment of eight sequences of internal transcribed spacer (ITS) 2 ribosomal DNA (rDNA) of Paratrichodorus allius retrieved from the ITS rDNA amplified by primer set TW81/AB28 showing insertions or deletions. 
populations of T. obtusus from North Carolina and Florida across sampling sites but not with geographical regions, based on sequence information of $18 \mathrm{~S}$ rDNA and the COI gene. Due to the abundant sequence information of $18 \mathrm{~S}$ rDNA in GenBank, we picked up one sequence from each haplotype as representative in the analysis. It was observed that the T. obtusus from Florida was closer to KT282335, which was originally from South Carolina and belonged to haplotype 1, whereas T. obtusus from South Carolina was clustered with others that belonged to haplotype 3 , supporting the independent evolution of this species. In this study, the D2-D3 of 28S rDNA is the most conserved region among and within species, compared with 18S rDNA and ITS rDNA (Tables 2 and 3). The ITS rDNA, which is more variable among and within species and has more evolutionary information compared with $28 \mathrm{~S}$ rDNA and $18 \mathrm{~S}$ rDNA, was employed to analyze the interspecies genetic diversity of $P$. allius collected from various geographic regions, including North Dakota, Minnesota, Washington, Oregon, and Idaho. The ITS rDNA, including ITS 1 rDNA, 5.8S rDNA, and ITS2 rDNA, was amplified by universal

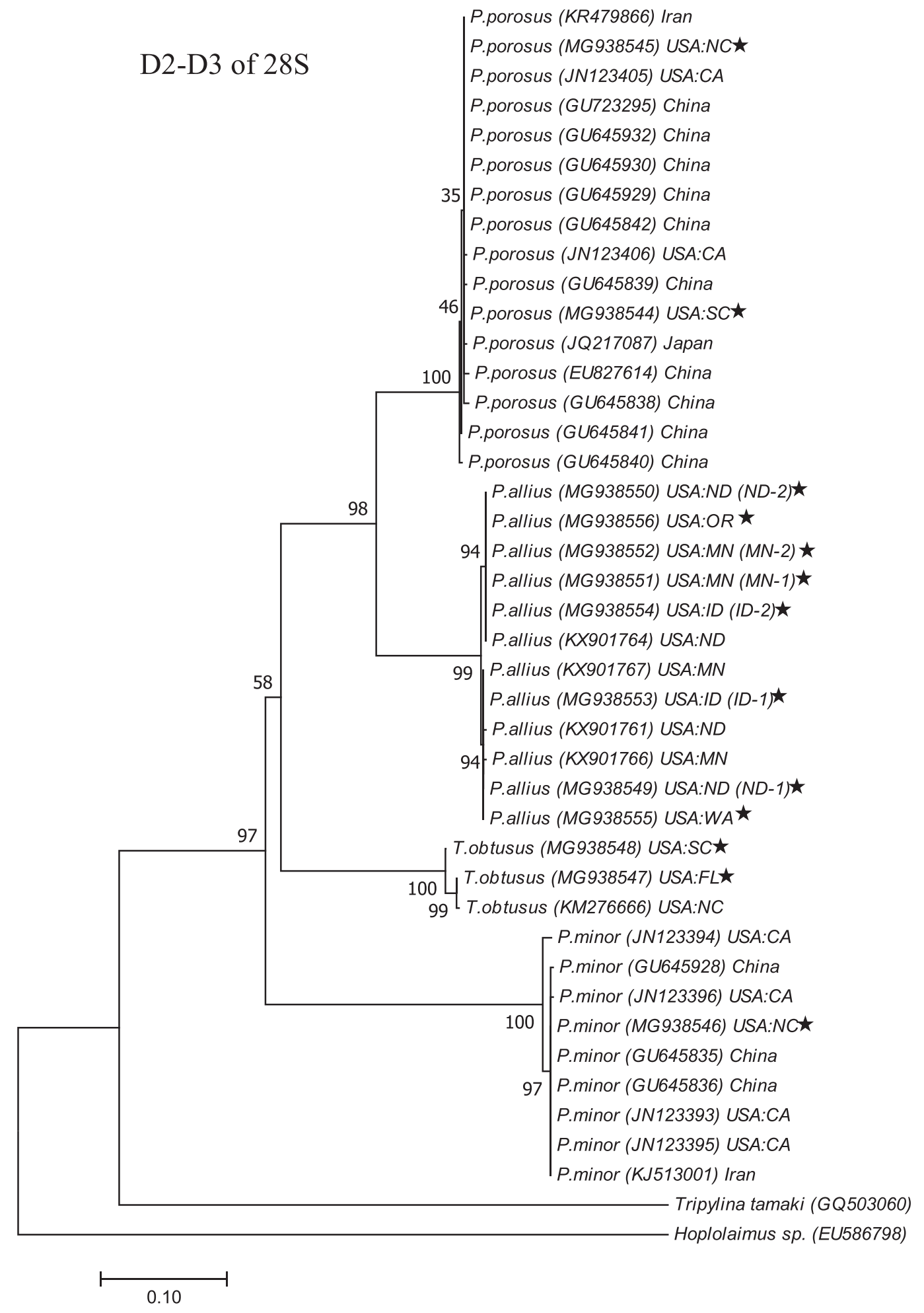

Fig. 3. Phylogenetic relations among Paratrichodorus allius, P. minor, P. porosus, and Trichodorus obtusus based on D2-D3 of 28S ribosomal DNA (rDNA) sequences. The tree was constructed by maximum-likelihood (ML) analysis using MEGA7. The scale bar of the ML tree represents the percentage of nucleotide substitutions per position. The percentage of trees in which the associated taxa clustered together is shown next to the branches. The $28 \mathrm{~S}$ rDNA sequences of Tripylina tamaki and Hoplolaimus sp. were used as outgroups. Sequences obtained in this study were labeled with five-pointed stars. 
primer pair TW81/AB28, which has not been used in previous studies of SRN. Unlike the Pratylenchus spp., where insertion or deletion events frequently occurred among species (De Luca et al. 2011), there are distinct insertions or deletions found in ITS2 rDNA among $P$. allius populations from different regions, in contrast with ITS1 rDNA mainly having transitions and transversions and 5.8S rDNA having no divergence. The insertions or deletions resulted in a maximum of $9.8 \%$ sequence divergence in ITS2 rDNA region, which appears to challenge the species identity because no ITS2 rDNA sequence of $P$. allius is available in GenBank. However, the same insertions or deletions were observed in the specimens of $P$. allius first reported in North Dakota and Minnesota in which the species identity was confirmed by both morphological measurements and molecular characterization of D2-D3 of 28S rDNA, 18S rDNA, and ITS1 rDNA (Yan et al. 2016a,b). No obvious association was found between genetic variation and geographic location, leading to the hypothesis of independent migrants, which is the same as observed for T. obtusus by Shaver et al. (2016).

\section{S rDNA partial-1}

P. porosus (GU645866) China

P. porosus (GU645862) China

$P$. porosus (GU645949) China

P. porosus (GU645956) China

$P$. porosus (JN123368) USA:CA

$P$. porosus (JQ217084) Japan

$P$. porosus (JQ217086) Japan

87 - P. porosus (KJ641548) China

$P$. porosus (GU645860) China

P. porosus (MG938558) USA:NC

$P$. porosus (MG938557) USA:SC

- P. porosus (JQ217085) Japan

$P$. porosus (GU645859) China

- P. porosus (GU645867) China

P. porosus (GU645952) China

P. porosus (GU645951) China

4 P. porosus (DQ345524) Portugal

- $P$. allius (KF887974) USA:OH

$99-P$. allius (AJ439623) USA:UT

99 P. allius (MG938568) USA:WA

$P$. allius (MG938569) USA:OR

$P$. allius (MG938563) USA:ND (ND-2)

$P$. allius (MG938562) USA:ND (ND-1)

$P$ allius (MG938565) USA:MN (MN-2)

$P$. allius (MG938564) USA:MN (MN-1)ћ

$P$. allius (KU094058) USA:ND

$P$. allius (KT892733) USA:MN

$P$. allius (KJ934124) USA:NC

$P$. allius (MG938567) USA:ID (ID-2)

$P$. allius (MG938566) USA:ID (ID-1) ᄎ

$P$. allius (AM269895) USA:WA

$P$ allius (AJ439572) USA:WA

$97 \quad T$. obtusus (KM276665) USA:NC

T. obtusus (JX279930) USA:SC

T. obtusus (KP984569) USA:FL

T. obtusus (KP984575) USA:FL

T. obtusus (MG938561) USA:SC

$T$. obtusus (KT282335) USA:SC

T. obtusus (KP984594)

3 T. obtusus (JX289834) USA:SC

33 T. obtusus (MG938560) USA:FL $\star$

P. minor (AJ438056) USA: SC

P. minor (MF434830) USA

- P. minor (KJ934126) USA:Puerto Rico

- P. minor (GQ995704) China

P. porosus (AJ438060) Portugal

P. porosus (AJ438059) Brazil

98 P. minor (MG938559) USA:NC

P. minor (MF434831) USA

- P. minor (MF423439) USA

P. minor (KJ934125) USA:SC

P. minor (JN123364) USA:CA

86 P. minor (GQ995710) China

P. minor (GQ995708) China

P. minor (GQ995703) China

P. minor (AM269897) USA:SC

P. minor (AJ438058) USA: AR

P. minor (AJ438057) USA: SC

P. minor (AJ438055) Brazil

P. minor (AJ438054) Brazil

P. minor (AJ438053) Portugal

Tripyla sp. (GQ503070)

Hoplolaimus sp. (HM246146)

\section{$\longmapsto$}

\subsection{0}

Fig. 4. Phylogenetic relations among Paratrichodorus allius, P. minor, P. porosus, and Trichodorus obtusus based on $18 \mathrm{~S}$ ribosomal DNA (rDNA) partial-1 sequences. The tree was constructed by maximum-likelihood (ML) analysis using MEGA7. The scale bar of the ML tree represents the percentage of nucleotide substitutions per position. The percentage of trees in which the associated taxa clustered together is shown next to the branches. The 18S rDNA sequences of Tripyla sp. and Hoplolaimus sp. were used as outgroups. Sequences obtained in this study were labeled with five-pointed stars. 
Morphological diversity of the same species among populations of nematodes and limited distinguished morphometrics between closely related species have challenged the diagnosis of nematodes and reflects the selection of management strategies (Riga et al. 2007; Robbins and Hirschmann 1974; Shaver et al. 2016). For instance, Shaver et al. (2016) reported the significant differences of morphometrics among T. obtusus populations from South Carolina and Florida. As another example, the sequence with GenBank accession number AJ439623, which was originally reported as species $P$. teres based on morphological measurements, was corrected to $P$. allius according to molecular-based phylogenetic inference and sequence analysis (Ilieva-Makulec et al. 2017). No research regarding the morphological diversity of $P$. allius was reported. Thus, in this study, the molecular characterization of $P$. allius, $P$. minor, $P$. porosus, and T. obtusus derived from multiple states in the United States and delivery of the rDNA sequence information enrich the genome database of these nematodes and provide more convenience for diagnosis of these species by developing molecular techniques such as species-specific

ITS1 rDNA

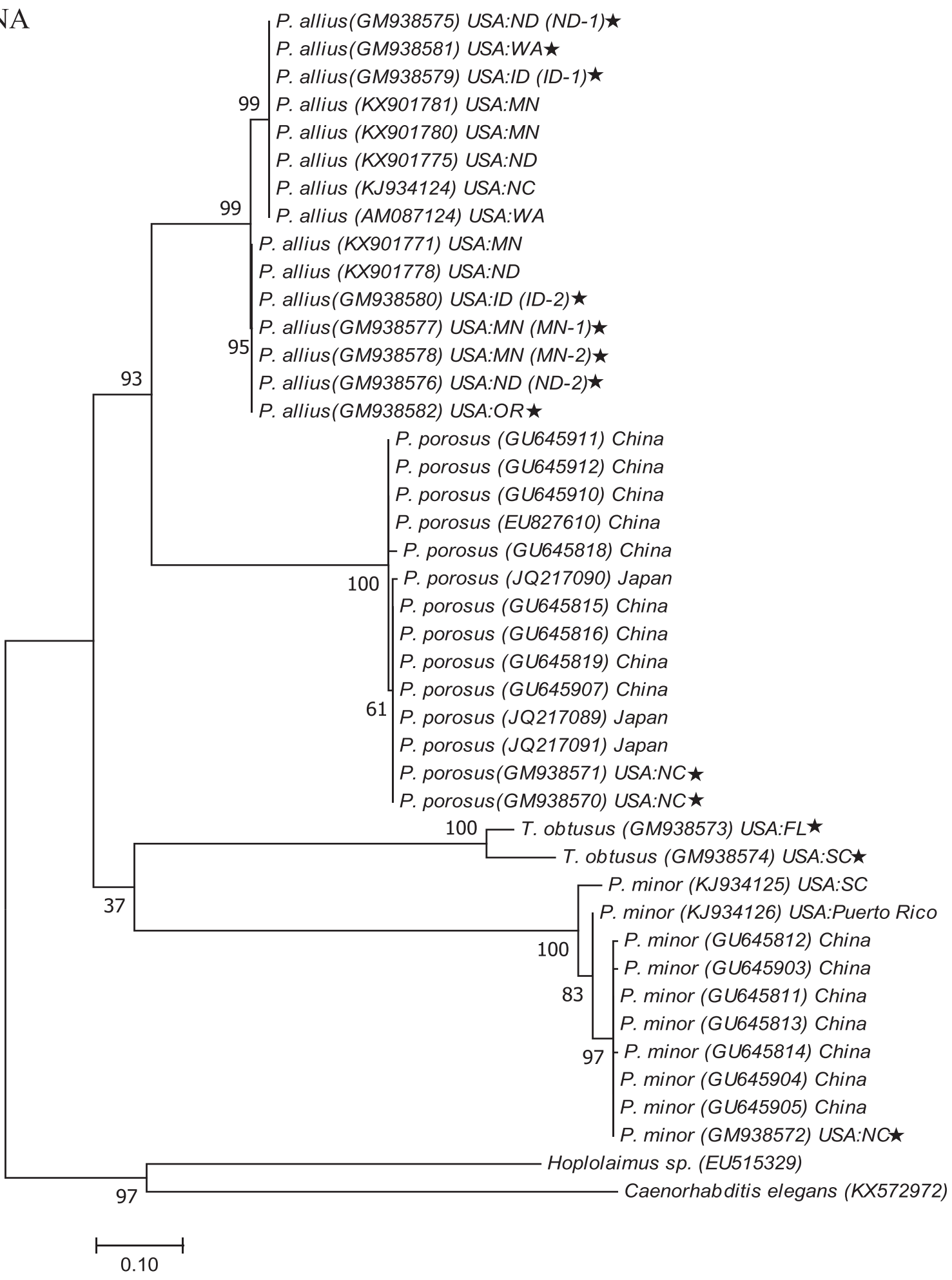

Fig. 5. Phylogenetic relations among Paratrichodorus allius, P. minor, P. porosus, and Trichodorus obtusus based on internal transcribed spacer (ITS) 1 ribosomal DNA (rDNA) sequences. The tree was constructed by maximum-likelihood (ML) analysis using MEGA7. The scale bar of the ML tree represents the percentage of nucleotide substitutions per position. The percentage of trees in which the associated taxa clustered together is shown next to the branches. The ITS1 rDNA sequences of Caenorhabditis elegans and Hoplolaimus sp. were used as outgroups. Sequences obtained in this study were labeled with five-pointed stars. 
single PCR or multiplex PCR. An important question is whether there is an association between nematode vector species and TRV serotypes, as proposed by Ploeg et al. (1992). As an important TRV vector, it is unknown whether $P$. allius's genetic divergence affects acquisition or transmission of TRV strains. Further studies on the detection of virus vectors among populations of $P$. allius from different geographic regions would be of interest.

\section{Acknowledgments}

We thank A. Plaisance, A. Upadhaya, and I. Chowdhury for collecting soil samples and assaying nematodes; and growers who allowed us to collect soil samples from their properties.

\section{Literature Cited}

Aleshin, V. X., Kedrova, O. S., Milyutina, I. A., Vladychenskaya, N. S., and Petrov, N. B. 1998. Relationships among nematodes based on the analysis of 18S rRNA gene sequences, molecular evidence for a monophyly of chromadorian and secernentian nematodes. Russ. J. Nematol. 6:175-184.

Altschul, S. F., Gish, W., Miller, W., Myers, E. W., and Lipman, D. J. 1990. Basic local alignment search tool. J. Mol. Biol. 215:403-410.

Blaxter, M., Mann, J., Chapman, T., Thomas, F., Whitton, C., Floyd, R., and Abebe, E. 2005. Defining operational taxonomic units using DNA barcode data. Philos. Trans. R. Soc. B. Biol. Sci. 360:1935-1943.

Blaxter, M. L., De Ley, P., Garey, J. R., Liu, L. X., Scheldeman, P., Vierstraete, A., Vanfleteren, J. R., Mackey, L. Y., Dorris, M., Frisse, L. M., Vida, J. T., and Thomas, W. K. 1998. A molecular evolutionary framework for the phylum Nematoda. Nature 392:71-75.

Boutsika, K., Blok, V. C., Phillips, M. S., Lewis, S. A., Robbins, R. T., Ferraz, L. C. C. B., and Brown, D. J. F. 2004a. Confirmation of the synonymy of Paratrichodorus christiei (Allen, 1957) Siddiqi, 1974 with P. minor (Colbran, 1956) Siddiqi, 1974 (Nematoda, Triplonchida) based on sequence data obtained for the ribosomal DNA 18 S gene. Nematology 6:145-151.

Boutsika, K., Brown, D. J. F., Philips, M. S., and Blok, V. C. 2004b. Molecular characterization of the ribosomal DNA of Paratrichodorus macrostylus, $P$. pachydermus, Trichodorus primitivus and $T$. similis (Nematoda: Trichodoridae). Nematology 6:641-654

Boutsika, K., Phillips, M. S., MacFarlane, S. A., Brown, D. J. F., Holeva, R. C., and Blok, V. C. 2004c. Molecular diagnostics of some trichodorid nematodes and associated Tobacco rattle virus. Plant Pathol. 53:110-116.

CABI/EPPO. 2002. Paratrichodorus minor [Distribution map]. Distribution Maps of Plant Diseases, October (Edition 1), Map 870. CABI, Wallingford, UK.

CABI/EPPO. 2009. Paratrichodorus porosus. [Distribution map]. Distribution Maps of Plant Diseases, October (Edition 1), Map 1066. CABI, Wallingford, UK.

Crow, W. T. 2005. Diagnosis of Trichodorus obtusus and Paratrichodorus minor on turfgrasses in the Southeastern United States. Plant Health Prog. doi: 10.1094/PHP-2005-0121-01-DG

Decraemer, W., and Baujard, P. 1998. A polytomous key for the identification of species of the family Trichodoridea Thorne, 1935 (Nematoda: Triplonchida). Fundam. Nematol. 21:37-62.

Decraemer, W., and Robbins, R. T. 2007. The who, what and where of Longidoridae and Trichodoridae. J. Nematol. 39:295-297.

De Ley, I. T., De Ley, P., Vierstraete, A., Karssen, G., Moens, M., and Vanfleteren, J. 2002. Phylogenetic analyses of Meloidogyne small subunit rDNA. J. Nematol. 34:319-327.

De Ley, P., Felix, A. M., Frisse, L. M., Nadler, S. A., Sternberg, P. W., and Thomas, W. K. 1999. Molecular and morphological characterization of two reproductively isolated species with mirror-image anatomy (Nematoda: Cephalobidae). Nematology 1:591-612.

De Luca, F., Reyes, A., Troccoli, A., and Castillo, P. 2011. Molecular variability and phylogenetic relationships among different species and populations of Pratylenchus (Nematoda: Pratylenchidae) as inferred from the analysis of the ITS rDNA. Eur. J. Plant Pathol. 130:415-426.

Duarte, I. M., Almeida, M. T. M., Brown, D. J. F., Marques, I., Neilson, R., and Decraemer, W. 2010. Phylogenetic relationships, based on SSU rDNA sequences, among the didelphic genera of the family Trichodoridae from Portugal. Nematology 12:171-180.

Duarte, I. M., Almeida, M. T. M., Duarte, M. M., Brown, D. J. F., and Neilson, R. 2011. Molecular diagnosis of trichodorid species from Portugal. Plant Pathol. 60:586-594.

Floyd, R., Abebe, E., Papert, A., and Blaxter, M. 2002. Molecular barcodes for soil nematode identification. Mol. Ecol. 11:839-850.

Hagenblad, J., Oliveira, H. R., Forsberg, N. E. G., and Leino, M. W. 2016. Geographical distribution of genetic diversity in Secale landrace and wild accessions. BMC Plant Biol. 16:23.

Heydari, R., Tanha Maafi, Z., and Decreamer, W. 2014. Morphological and molecular characterisation of Trichodorus golestanensis (Nematoda: Trichodoridae), a new species from Iran. Eur. J. Plant Pathol. 140:329-340.

Holeva, R., Phillips, M. S., Neilson, R., Brown, D. J. F., Young, V., Boutsika, K., and Blok, V. C. 2006. Real-time PCR detection and quantification of vector trichodorid nematodes and Tobacco rattle virus. Mol. Cell. Probes 20:203-211.
Holterman, M., van der Wurff, A., van den Elsen, S., van Megen, H., Bongers, T. Holovachov, O. V., Bakker, J., and Helder, J. 2006. Phylum-wide analysis of SSU rDNA reveals deep phylogenetic relationships among nematodes and accelerated evolution toward crown Clades. Mol. Biol. Evol. 23: 1792-1800.

Holterman, M. H. M., Holovachov, O. V., Van Den Elsen, S. J. J., Van Megen, H. H. B., Bongers, A. M. T., Bakker, J., and Helder, J. 2008. Small subunit ribosomal DNA-based phylogeny of basal Chromadoria (Nematoda) suggests that transitions from marine to terrestrial habitats (and vice versa) require relatively simple adaptations. Mol. Phylogenet. Evol. 48:758-763.

Huang, D., Yan, G. P., Gudmestad, N., and Skantar, A. M. 2017a. Quantification of Paratrichodorus allius in DNA extracted from soil using TaqMan probe and SYBR Green real-time PCR assays. Nematology 19:987-1001.

Huang, D., Yan, G. P., and Skantar, A. M. 2017b. Development of real-time and conventional PCR assays for identifying stubby root nematode Paratrichodorus allius. Plant Dis. 101:964-972.

Ilieva-Makulec, K., Rybarczyk-Mydłowska, K., Winiszewska, G., Flis, Ł., Tereba A., Kowalewska, K., and Malewski, T. 2017. Morphological and molecular analysis of Paratrichodorus teres (Hooper 1962) (Nematoda: Trichodoridae): A groundwork for discussion on the phylogeny and pathogenicity of Paratrichodorus species. Eur. J. Plant Pathol. 148:907-917.

Janssen, T., Karssen, G., Orlando, V., Subbotin, S. A., and Bert, W. 2017. Molecular characterization and species delimiting of plant-parasitic nematodes of the genus Pratylenchus from penetrans group (Nematode: Pratylenchidae). Mol. Phylogenet. Evol. 117:30-48.

Joyce, S. A., Reid, A. P., Driver, F., and Curran, J. 1994. Application of polymerase chain reaction (PCR) methods to the identification of entomopathogenic nematodes. Pages 178-187 in: . Proc. Symp. Workshop Genet. Entomopathogenic Nematode-Bacterium Complexes, St. Patrick's College, Maynooth, County Kildare, Ireland. A. M. Burnell, R. U. Ehlers, and J. P. Masson, eds. Luxembourg, DGXII, European Commission.

Kirk, W. W., Gieck, S. L., Crosslin, J. M., and Hamm, P. B. 2008. First report of corky ringspot caused by Tobacco rattle virus on potatoes (Solanum tuberosum) in Michigan. Plant Dis. 92:485.

Kumar, S., Stecher, G., and Tamura, K. 2016. MEGA7: Molecular evolutionary genetics analysis version 7.0 for bigger datasets. Mol. Biol. Evol. 33:1870-1874.

Kumari, S., and Subbotin, S. A. 2012. Molecular characterization and diagnostics of stubby root and virus vector nematodes of the family Trichodoridae (Nematoda: Triplonchida) using ribosomal RNA genes. Plant Pathol. 61: 1021-1031.

Lazarova, S. S., Mallock, G., Oliveira, C. M. G., Hubschen, J., and Neilson, R. 2006 Ribosomal and mitochondrial DNA analyses of Xiphinema americanum-group populations. J. Nematol. 38:404-410.

Lopez-Nicora, H. D., Mekete, T., Sekora, N., and Niblack, T. L. 2014. First report of the stubby-root nematode (Paratrichodorus allius) from a corn field in Ohio. Plant Dis. 98:1164.

Mojtahedi, H., Santo, G. S., Handoo, Z., Crosslin, J. M., Brown, C. R., and Thomas, P. E. 2000. Distribution of Paratrichodorus allius and Tobacco rattle virus in Pacific Northwest potato fields. J. Nematol. 32:447.

Mullin, P. G., Harris, T. S., and Powers, T. O. 2005. Phylogenetic relationships of Nygolaimina and Dorylaimina (Nematoda: Dorylaimida) inferred from small subunit ribosomal DNA sequences. Nematology 7:59-79.

Neilson, R., Ye, W., Oliveira, C. M. G., Hübschen, J., Robbins, R. T., Brown, D. J F., and Szalanski, A. L. 2004. Phylogenetic relationships of Longidoridae species (Nematoda: Longidoridae) from North America inferred from $18 \mathrm{~S}$ rDNA sequence data. Helminthologia 41:209-215.

Plaisance, A., and Yan, G. P. 2015. Comparison of two nematode extraction techniques. J. Nematol. 47:263-264.

Ploeg, A. T., Brown, D. J. F., and Robinson, D. J. 1992. The association between species of Trichodorus and Paratrichodorus vector nematodes and serotypes of tobacco rattle tobravirus. Ann. Appl. Biol. 121:619-630.

Riga, E., Karanastasi, E., Oliveira, C. M. G., and Neilson, R. 2007. Molecular identification of two stubby root nematode species. Am. J. Potato Res. 84:161-167.

Riga, E., and Neilson, R. 2005. First report of the stubby-root nematode Paratrichodorus teres, from potato in the Columbia Basin of Washington State. Plant Dis. 89:1361.

Robbins, R. T., and Hirschmann, H. 1974. Variation among populations of Belonolaimus longicaudatus. J. Nematol. 6:87-94.

Shaver, B. R., Marchant, S., Martin, S. B., and Agudelo, P. 2016. 18S rRNA and COI haplotype diversity of Trichodorus obtusus from turfgrass in South Carolina. Nematology 18:53-65.

Subbotin, S. A., Ragsdale, E. J., Mullens, T., Roberts, P. A., Mundo-Ocampo, M., and Baldwin, J. G. 2008. A phylogenetic framework for root lesion nematodes of the genus Pratylenchus (Nematoda): Evidence from 18S and D2-D3 expansion segments of 28S ribosomal RNA genes and morphological characters. Mol. Phylogenet. Evol. 48:491-505

Taylor, C. E., and Brown, D. J. F. 1997. Nematode Vectors of Plant Viruses. CAB International, Wallingford, UK.

Thompson, J. D., Gibson, T. J., Plewniak, F., Jeanmougin, F., and Higgins, D. G. 1997. The CLUSTAL_X windows interface: Flexible strategies for multiple sequence alignment aided by quality analysis tools. Nucleic Acids Res. 25:4876-4882. Van Megen, H., Elsen, S. V. D., Holterman, M., Karssen, G., Mooyman, P., Bongers, T., Holovachov, O., Bakker, J., and Helder, J. 2009. A phylogenetic 
tree of nematodes based on about 1200 full-length small subunit ribosomal DNA sequences. Nematology 11:927-950.

Waeyenberge, L., Viaene, N., and Moens, M. 2009. Species-specific duplex PCR for the detection of Pratylenchus penetrans. Nematology 11:847-857.

Wang, F., Zhang, S., Liu, M. G., Lin, X. S., Liu, H. J., Peng, Y. L., Lin, Y., Huang, J. B., and Luo, C. X. 2014. Genetic diversity analysis reveals that geographical environment plays a more important role than rice cultivar in Villosiclava virens population selection. Appl. Environ. Microbiol. 80:2811-2820.

Yan, G. P., Khan, M. F., Huang, D., Lai, X., and Handoo, Z. A. 2016a. First report of the stubby root nematode Paratrichodorus allius on sugar beet in Minnesota. Plant Dis. 100:1022.
Yan, G. P., Plaisance, A., Huang, D., Upadhaya, A., Gudmestad, N. C., and Handoo, Z. A. 2016b. First report of the stubby root nematode Paratrichodorus allius on potato in North Dakota. Plant Dis. 100:1247.

Ye, W., Zeng, Y., and Kerns, J. 2015a. First report of Trichodorus obtusus on turfgrass in North Carolina, U.S.A. Plant Dis. 99:291.

Ye, W., Zeng, Y., and Kerns, J. 2015b. Molecular characterisation and diagnosis of root-knot nematodes (Meloidogyne spp.) from turfgrasses in North Carolina, USA. PLoS One 10:e0143556.

Zeng, Y., Ye, W., Bruce Martin, S., Martin, M., and Tredway, L. 2012. Diversity and occurrence of plant-parasitic nematodes associated with golf course turfgrasses in North and South Carolina, USA. J. Nematol. 44:337-347. 